\title{
Contextual Teaching and Learning Berbantuan Media Audio Visual Berpengaruh Terhadap Kompetensi Pengetahuan IPA Siswa SD
}

\author{
Ni Kadek Dewi Antari ${ }^{1}$, Gusti Ngurah Sastra Agustika² \\ 12Prodi Pendidikan Dasar Guru Sekolah Dasar, FIP \\ Universitas Pendidikan Ganesha, Singaraja, Indonesia \\ e-mail: dewiantari9737@gmail.com, gn.sastra.a@undiksha.ac.id
}

\begin{abstract}
Abstrak
Penelitian ini dilatarbelakangi oleh rendahnya kompetensi pengetahuan siswa pada mata pembelajaran IPA yang ditandai dari hasil Penilaian Tengah Semester (PTS) kompetensi pengetahuan IPA siswa lebih rendah dari standar nilai KKM, dari 413 siswa 165 siswa atau $40 \%$ tuntas, sedangkan 248 siswa atau $60 \%$ belum tuntas. Demikan pula pada pelaksanaan pembelajaran yang masih bersifat konvensional. Berdasarkan permasalahan tersebut, maka penelitian ini bertujuan untuk mencari pengaruh yang signifikan pendekatan contextual teaching and learning (CTL) berbantuan media audio visual terhadap kompetensi pengetahuan IPA siswa SD. Jenis penelitian ini adalah penelitian eksperimen semu dengan rancangan non-equilevalent control group design. Populasi penelitian in berjumlah 413 siswa dan sampel penelitian 64 siswa. Penentuan sampel menggunakan teknik random sampling. Data dikumpulkan menggunakan metode tes, analisis data yang digunakan pada penelitian ini, yaitu teknik analisis statistik inferensial. Hasil dianalisis memakai uji-t. membuktikan thitung $=7,329>$ tabel $=2,000$ pada $\alpha=0,05$ dan $\mathrm{dk}=62$, maka $\mathrm{H}_{0}$ ditolak dan $\mathrm{H}_{\mathrm{a}}$ diterima mengartikan terdapat perbedaan yang signifikan kompetensi pengetahuan IPA kelompok siswa yang dibelajarkan dengan pendekatan contextual teaching and learning berbantuan media audio visual dan kelompok siswa yang dibelajarkan dengan pembelajaran konvensional. Didasarkan pada hasil uji hipotesis, maka pendekatan contextual teaching and learning berbantuan media audio visual berpengaruh terhadap kompetensi pengetahuan IPA siswa SD. Implikasi hasil penelitian ini dapat digunakan untuk mendalami objek penelitian sejenis sebagai salah satu bahan referensi sehingga mampu meningkatkan kompetensi pengetahuan IPA.
\end{abstract}

Kata kunci: CTL, audio visual, IPA

\begin{abstract}
This research is motivated by the low competency of students knowledge in natural science subjects which is marked by the results of the Mid-Semester Assessment of science students competency of science is lower than the KKM standard values, of 413 students 165 students or $40 \%$ complete, while 248 students or $60 \%$ have not finished. Similarly, the implementation of learning is still conventional. Based on these problems, this study aims to look for a significant influence on the contextual teaching and learning (CTL) approach assisted by audio visual media on the science competency of science students in elementary school. This type of research is a quasi-experimental study with a nonequilevalent control group design. The population of the study was 413 students and the study sample was 64 students. Determination of the sample using random sampling techniques. Data were collected using a test method, data analysis used in this study, namely inferential statistical analysis techniques. The results were analyzed using t-test. prove tcount $=7.329>$ table $=2,000$ at $\alpha=0.05$ and $\mathrm{dk}=62$, then $\mathrm{H}_{0}$ is rejected and $\mathrm{Ha}$ is accepted to mean there is a significant difference in the science knowledge competence of students groups being taught with contextual teaching and learning aided by audio-visual media and student groups which is taught by conventional learning. Based on the results of hypothesis testing, the contextual teaching and learning approach assisted by audio
\end{abstract}

\footnotetext{
${ }^{*}$ Corresponding author.
}

Received 20 April 2020, Accepted 20 Juni 2020; Available online 5 Juli 2020 (C) 2020 MI All Rights Reserved 
visual media influences the science knowledge competency of elementary school. The implications of the results of this study can be used to explore similar research objects as one of the reference materials so as to increase the competence of science knowledge.

Keywords: CTL, audio visual, IPA

\section{Pendahuluan}

Pendidikan selalu melibatkan aktivitas manusia, baik yang dilakukannya sendiri maupun terhadap orang lain. Pantas saja pendidikan merupakan kebutuhan utama manusia. Salah satu hal penting untuk meningkatkan SDM yang berkualitas adalah melalui pendidikan. Dengan meningkatkan SDM yang berkualitas akan sangat berperan baik pada kualitas pendidikan terutama pada pendidikan jenjang sekolah dasar (SD). Pendidikan di SD merupakan tahap awal siswa mengetahui berbagai macam pelajaran dan merupakan bekal untuk membangun pengetahuan selanjutnya. Pada pelaksanaan pendidikan di sekolah dasar, perlu adanya suatu kurikulum yang dapat mendukung proses pendidikan yang baik. Pada Kurikulum 2013 (K13) muatan-muatan pelajaran di padukan ke dalam berbagai tema. Dengan begitu pengetahuan yang dimiliki siswa tidak terpisah-pisah melainkan terpadu secara keseluruhan. Untuk meningkatkan kualitas pendidikan tersebut perlu dilakukan sebuah penelitian yang mampu memecahkan masalah yang terjadi di lapangan sehingga rencana atau kurikulum yang telah digagas tidak hanya sekedar formalitas belaka. Telah banyak penelitian yang berusaha untuk meningkatkan kualitas pendidikan namun jika penerapan dilapangan tidak maksimal akan menghasilkan output yang kurang optimal pula. Seperti penelitian oleh Paramita (2019) menyatakan walau pemerintah telah merancang proses pembelajaran dalam sebuah kurikulum dengan amat baik apabila proses belajar mengajar dalam pelaksanaannya kurang maksimal maka tujuan pembelajaran yang ditargetkan sepenuhnya tidak akan tergapai secara optimal. Jika hal ini terus terjadi dan terabaikan tentunya akan bedampak buruk bagi pengembangan kualitas pendidikan di Indonesia.

Terdapat kesenjangan pada pelaksanaannya di lapangan berdasarkan informasi yang diperoleh dari hasil observasi di SDN Gugus 1 Kuta Utara pada tanggal 26-2 November 2019, terdapat permasalahan-permasalahan yang muncul saat berlangsungnya proses pembelajaran seperti perhatian siswa masih belum sepenuhnya terfokus ke pembelajaran, siswa sulit termotivasi dan kurang aktif serta bersemangat dan pembelajaran yang kurang bermakna. Fakta lainnya juga diungkapkan oleh Herlina (2020) menyatakan pada kenyataan teori dengan di sekolah berbeda, siswa cenderung hanya mendengarkan materi sehingga pembelajaran menjadi monoton. Pendapat yang sama juga dijelaskan oleh (Nababan, 2018) menyatakan guru lebih sering menggunakan pembelajaran konvensional dalam mengajar dikelas. Berkaitan dengan pendapat sebelumnya Rahmawati (2019) menyatakan untuk itu, hendaknya guru tidak hanya sekedar menyampaikan materi, tetapi juga harus mencari suatu pendekatan yang cocok untuk digunakan agar siswa cepat memahami materi yang telah disampaikan. Fokus permasalahan tersebut terlihat dari Penilaian Tengah Semester (PTS) kompetensi pengetahuan IPA siswa lebih rendah dari standar nilai KKM. Pemerolehan nilai PTS semester I kelas V SDN Gugus I Kuta Utara yaitu, dari 413 siswa 165 siswa atau 40\% tuntas, sedangkan 248 siswa atau $60 \%$ belum tuntas.

Proses pembelajaran yang kurang direncanakan dengan maksimal akan berpengaruh kepada siswa, terutama dari segi kompetensi pengetahuan siswa yang belum optimal. Menurut Astuti (2015) pembelajaran yang memfokuskan penguasaan kompetensi mesti berpusat kepada siswa dan memberikan pengetahuan belajar secara langsung yang bersangkut-paut dan kontekstual dalam kehidupan nyata. Sehingga, peran guru dalam merancang sebuah pembelajaran menjadi hal penting demi mencapai pembelajaran yang diinginkan. Pusat persoalan penelitian ini adalah kompetensi pengetahuan IPA siswa. Ariestuti (2014) menyatakan belajar IPA sepatutnya tepat dengan perkembangan pemikiran anak, sehingga pembelajaran menjadi efektif dan menyenangkan. Sementara Sugiarta (2013) berpendapat pembelajaran IPA seharusnya dirancang bermakna, mengarah pada proses. 
Muatan pelajaran IPA di SD mempelajari hal-hal yang erat dengan kehidupan manusia berrsama alam sekitar. IPA sebagai pembelajaran wajib di SD tidak terlepas dari hubungan yang luas dengan kehidupan di masyarakat sehingga saat siswa mempelajari IPA perlu suatu rancangan pembelajaran yang mengarahkan siswa mencapai pembelajaran bermakna dan memberikan pengalaman langsung (nyata).

Solusi yang dapat ditemukan untuk menjawab permasalahan-permasalahan diatas adalah memperbaiki kegiatan belajar mengajar dengan merancang pembelajaran yang bermakna dan dapat menyenagkan serta menarik. Untuk itu diperlukan komponen serta perangkat dalam pendukung proses pembelajaran. Puspasari (2019) berpendapat pendekatan adalah tahap awal ide terbentuk dalam melihat suatu masalah atau objek kajian. Pada mata pelajaran IPA pendekatan yang harus diterapkan adalah pendekatan yang mampu menyertakan siswa secara langsung dalam pembelajarannya (Marliani, 2018). Hal senada juga dinyatakkan oleh (Dewi, 2018) sebagai pendorong perkembangan kognitif siswa, pengalaman langsung memiliki peranan penting. Maka, perlu adanya pengembangkan ide yang kreatif dalam menerapkan pendekatan serta sumber belajar yang inovatif agar proses pembelajaran bermakna dan menarik.

Pendekatan contextual teaching and learning (CTL) sebagai salah satu pilihan pendekatan pembelajaran. Pada pendekatan ini guru memberi kaitan antara bahan ajar yang akan dibelajarkan dengan kehidupan nyata peserta didik (Widiasworo, 2018). Kasuma ( 2017) menyatakan siswa dapat mengerti penyampaian guru karena pendekatan CTL menghadirkan atau mengaitkan bahan pelajaran dengan dunia sesungguhnya yang dialami oleh siswa. Pendekatan CTL menganut aliran konstruktivism, artinya siswa belajar melalui "mengalami" bukan "menghafal" (Suprianto, 2016). Melalui konsep tersebut diharapkan pembelajaran menjadi bermakna karena pembelajaran berlangsung alamiah. Selain penggunaan pendekatan pembelajaran, komponen pendukung lainnya juga dibutuhkan dalam proses pembelajaran. Arsyad (2013) mengatakan terdapat dua komponen atau elemen yang diperlukan dalam pembelajaran yakni media dan metode pembelajaran. Unsur-unsur tersebut saling terkait dan mempunyai arti yang penting. Alangkah baiknya pembelajaran ditunjang dengan pemanfaatan sumber-sumber belajar lain selain buku sehingga pengetahuan siswa tidak terbatas pada buku dan dapat memperluas pengetahuan yang diperoleh siswa. Sumber belajar yang bisa dimanfaatkan yakni media pembelajaran, contohnya media audio visual. Media audio visual berperan dengan mentransfer tulisan dan kata yang diucapkan (Trisnadewi, 2014). Media audio visual memiliki unsur suara serta gambar (Djamarah, 2013). Media ini memiliki keunggulan karena menggunakan dua unsur, yakni unsur gambar dan suara. Melalui keunggulan unsur suara dan gambar siswa terbantu dengan diilustrasikannya kaitan materi pembelajaran.

Pernyataan-pernyataan tersebut juga didukung dengan hasil penelitian oleh Ariestuti (2014) keaktifan dan hasil belajar IPA siswa meningkat dengan menggunakan pendekatan contextual teaching and learning (CTL). Samriani (2016) melalui diterapkannya pendekatan contextual teaching and learning (CTL) mampu meningkatkan hasil belajar IPA. Serta hasil penelitian Mahardita (2017) pendekatan kontekstual berbantuan media audio visual memengaruhi hasil belajar IPA.

Didasarkan pada permasalaham-permasalahan tersebut serta mengacu pada penelitian sebelumnya, maka penelitian ini bertujuan untuk mencari pengaruh pendekatan Contextual Teaching and Learning berbantuan media audio visual terhadap kompetensi pengetahuan IPA Siswa SD. Penelitian ini memiliki kelebihan dalam konsep yang digunakan karena memadukan pendekatan contextual teaching and learning sebagai pembelajaran bermakna dengan media audio visual yang dapat menarik perhatian siswa sehingga proses pembelajaran berlangsung sesuai apa yang diharapkan oleh tujuan pembelajaran. 


\section{Metode}

Jenis penelitian yang digunakan adalah penelitian eksperimen semu (quasy experimental design). Rancangan yang dipergunakan adalah Nonequivalent Control Group Design. Seluruh siswa kelas V SDN Gugus I Kuta Utara Tahun Ajaran 2019/2020 merupakan populasi pada penelitian ini yang berjumlah 413 siswa dan terbagi kedalam 14 kelas pada 7 sekolah dasar. Penentuan sampel ditempuh dengan teknik random sampling yakni mengundi kelas yang sudah terbentuk artinya peneliti tidak diizinkan memilah atau mengacak siswa (individu) dalam kelas sehingga tiap-tiap kelas sampel memiliki kesamaan peluang untuk menjadi sampel penelitian. Pengundian dilakukan dengan memberi nomor urut tiap-tiap kelas $\checkmark$ pada populasi dimasing-masing kertas yang telah dibuat sedemikian rupa. Kertas digulung dan dimasukkan kedalam kotak kemudian diundi, selanjutnya diperoleh dua kelompok sampel.

Terdapat tiga tahapan saat penelitian dilakukan, yakni: (a) tahap persiapan eksperimen meliputi; melaksanakan wawancara bersama kepala Gugus dan wali kelas untuk mendapatkan informasi dasar seperti jumlah siswa kelas $V$ dan ada tidaknya kelas yang diunggulan, menyusun RPP beserta LKS berdasarkan kurikulum dan silabus, menyiapkan sumber-sumber serta media pembelajaran, menyusun instrumen penelitian, mengkonsultasikan instrumen, melakukan validasi instrumen penelitian, menentukan sampel, menguji kesetaraan kedua kelompok sampel, penentuan kelompok eksperimen dan kontrol, (b) tahap pelaksanaan eksperimen meliputi; memberikan perlakuan kepada kelompok eksperimen, treatment dilakukan enam kali pada tiap-tiap kelompok sampel, memberikan posttest pada kedua kelompok sampel pada akhir penelitian, (c) tahap akhir eksperimen meliputi; analisis data, melaksanakan uji hipotesis.

Sebelum memberikan treatment, masing-masing kelompok sampel akan diberikan pretest untuk mengetahui kesetaraan kedua kelompok. Terlebih dahulu pretest diuji prasyarat analisisnya yaitu uji normalitas memakai Chi Kuadrat, dan uji homogenitas varian memakai uji $F$ yang kemudian setelah data homogen dan sebaran data berdistribusi normal selanjutnya menguji kesetaraan memakai uji-t.

Pengumpulan data posttest memakai metode tes. Namun terlebih dahulu tes dibuatkan kisi-kisi instrumen. Instrumen yang dipakai berupa tes objektif pilihan ganda biasa (PGB) menggunakan indikator C1-C6 yang terdapat pada ranah kognitif (pengetahuan). Instrumen tersebut terlebih dahulu dikonsultasikan pada ahlinya kemudian sebelum diujicobakan, instrumen penelitian diuji validitas teoritik terlebih dahulu kemudian dilakukan uji coba sebanyak 50 butir soal. Setelah itu dianalisis validitas butir, daya pembeda, tingkat kesukaran dan reliabitasnya. Terdapat 36 butir soal yang sesuai dengan syarat pada uji coba tersebut. Kisi - kisi posttest kompetensi pengetahuan IPA disajikan pada tabel 1.

Tabel 1. Kisi - kisi Posttest Kompetensi Pengetahuan IPA

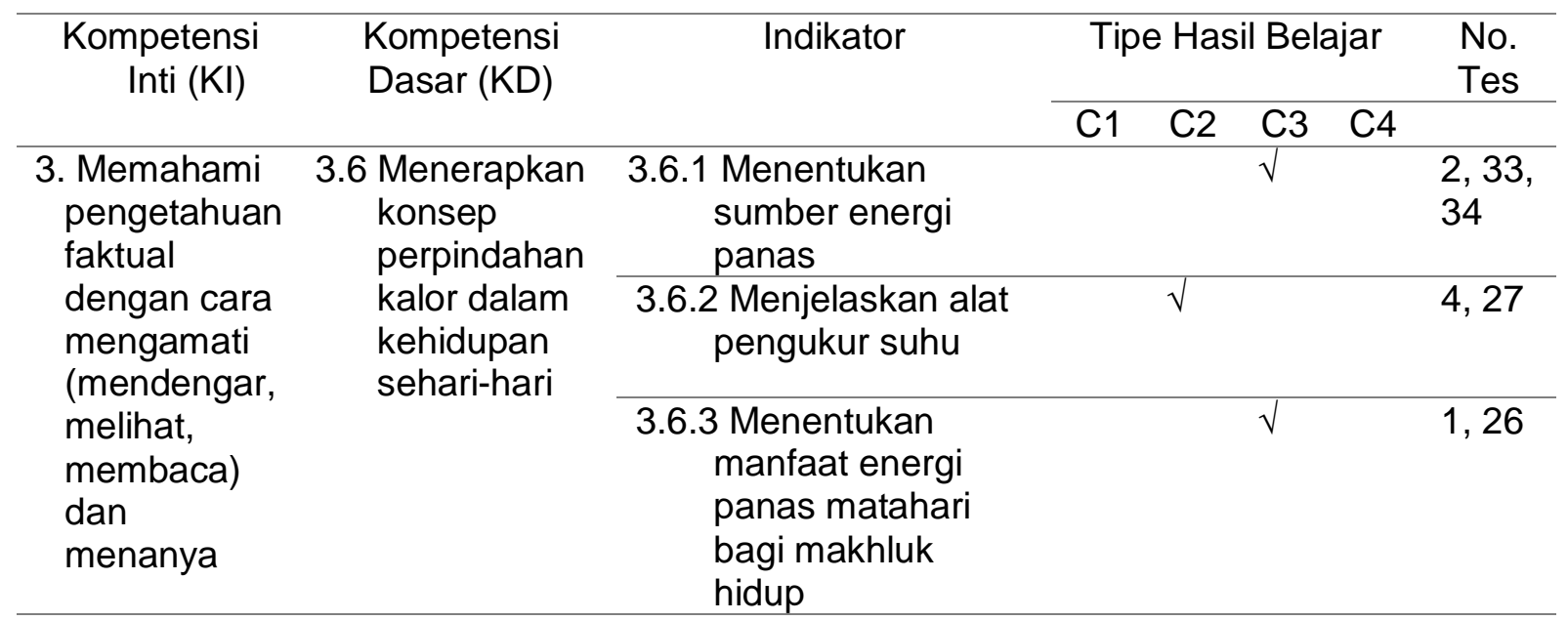




berdasarkan
rasa ingin
tahu tentang
dirinya,
makhlu
ciptaan
Tuhan dan
kegiatannya,
dan benda -
benda yang
dijumpainya
di rumah,
sekolah, dan
tempat
bermain.

\begin{tabular}{ccc}
$\begin{array}{c}\text { 3.6.4 Menjelaskan } \\
\text { perpindahan kalor } \\
\text { secara konveksi }\end{array}$ & $\sqrt{ }$ & 9,28 \\
$\begin{array}{c}\text { 3.6.5 Menjelaskan } \\
\text { perpindahan kalor }\end{array}$ & $\sqrt{ }$ \\
$\begin{array}{c}\text { secara konduksi } \\
\text { 3.6.6 Menjelaskan } \\
\text { perpindahan kalor } \\
\text { secara radiasi }\end{array}$ & $\sqrt{ }$ & 11,35 \\
\hline
\end{tabular}

\begin{tabular}{lc}
\hline $\begin{array}{l}\text { 3.6.7 Memberikan } \\
\text { contoh } \\
\text { perpindahan } \\
\text { panas secara } \\
\text { konduksi, konveksi } \\
\text { dan radiasi }\end{array}$ & 6,7, \\
\hline $\begin{array}{l}\text { 3.6.8 Menentukan } \\
\text { bahan yang dapat } \\
\text { dan tidak dapat } \\
\text { menghantarkan } \\
\text { panas dengan baik }\end{array}$ & \\
\hline 3.6.9 Menganalisis & 12,13, \\
benda-benda yang & 16 \\
terbuat dari bahan & \\
isolator & \\
\hline
\end{tabular}
3.6.10 Menganalisis $\quad \sqrt{ } 15,17$, benda-benda yang 19 , terbuat dari bahan $\quad 24,30$ konduktor

3.6.12 Mengidentifikasi $\sqrt{ }$ 23, 31, benda berbahan 32 konduktor

\begin{tabular}{lll}
\hline $\begin{array}{c}\text { 3.6.13 Mengidentifikasi } \\
\text { benda berbahan } \\
\text { isolator }\end{array}$ & $\sqrt{ }$ & 18, \\
$\begin{array}{l}\text { 3.6.15 Menjelaskan } \\
\text { penyusutan, }\end{array}$ & $\sqrt{ }$ \\
pemuaian & & 5,14, \\
terhadap suatu & & \\
benda & &
\end{tabular}

Hipotesis penelitian akan diuji dengan uji-t, karena membandingkan dua skor rata-rata untuk membuktikan bahwa perbedaan skor antar kedua kelompok bukan merupakan perbedaan yang terjadi secara kebetulan melainkan perbedaan antar dua kelompok terjadi secara nyata. Sebelum menguji hipotesis terdapat dua prasyarat analisis yang harus dilalui yakni uji normalitas dan uji homogenitas. Rumus yang dipergunakan untuk menguji normalitas 
sebaran data tiap kelompok menggunakan rumus Chi-Square. Uji Homogenitas Varian menggunakan uji F. Selanjutnya menguji hipotesis menggunakan uji-t dengan polled varian.

\section{Hasil dan Pembahasan}

Setelah pemberian perlakuan (treatment) sebanyak enam kali pada masing-masing kelompok sampel, diakhir pembelajaran diberikan posttest. Hasil analisis data selengkapnya ditunjukkan pada tabel 2 .

Tabel 2. Analisis Deskriptif Data Penelitian

\begin{tabular}{lcc}
\hline \multicolumn{1}{c}{ Data Statistik } & Kelompok Eksperimen & Kelompok Kontrol \\
\hline Nilai Minimum & 67 & 44 \\
Nilai Maksimum & 94 & 86 \\
Rata-rata & 80,85 & 66,85 \\
Modus & 80,78 & 67,5 \\
Median & 85,16 & 66,83 \\
Varian & 43,99 & 75,99 \\
Standar Deviasi & 6,63 & 8,51 \\
\hline
\end{tabular}

Terdapat dua uji prasyarat yang wajib terpenuhi sebelum menguji hipotesis penelitian. Data penelitian harus memenuhi varian data homogen antar kelompok dan sebaran data berdistribusi normal disetiap kelompok. Hasil Uji sebaran dan homogenitas varian data selengkapnya dapat dilihat pada tabel 3.

Tabel 3. Hasil Uji Sebaran dan Uji Homogenitas Varian Data Kompetensi Pengetahuan IPA

\begin{tabular}{lccccc}
\hline \multicolumn{1}{c}{ Kelompok } & $\chi_{\text {hitung }}^{2}$ & $\chi_{\text {tabel }}^{2}$ & $F_{\text {hitung }}$ & $F_{\text {tabel }}$ & Keterangan \\
\hline Eksperimen & 9,970 & 11,070 & 1,73 & 1,84 & $\begin{array}{c}\text { Berdistribusi Normal dan } \\
\text { Kontrol }\end{array}$ \\
\hline
\end{tabular}

Hasil uji normalitas kelompok eksperimen didapatkan $\chi^{2}$ hitung $=9,970$ kemudian nilai tersebut dibandingkan dengan $\chi^{2}$ tabel $=11,070$. Hal ini menunjukkan bahwa $\chi^{2}$ hitung $<\chi^{2}$ tabel maka sebaran data hasil kompetensi pengetahuan IPA pada kelompok eksperimen berdistribusi normal.

Hasil uji normalitas kelompok kontrol didapatkan $\chi^{2}$ hitung $=4,680$ kemudian nilai tersebut dibandingkan dengan $\chi^{2}$ tabel $=11,070 . \chi^{2}$ hitung $<\chi^{2}$ tabel maka sebaran data hasil kompetensi pengetahuan IPA pada kelompok kontrol berdistribusi normal.

Hasil uji homogenitas varian data kompetensi pengetahuan IPA didapatkan $F_{\text {hitung }}=1,73$ dan $F_{\text {tabel }}=1,84$. $F_{\text {hitung }}<F_{\text {tabel, }}$ maka varian data kedua kelompok sampel homogen.

Hasil analisis uji-t selengkapnya disajikan pada tabel 4.

Tabel 4. Hasil Analisis Uji-t Data Kompetensi Pengetahuan IPA

\begin{tabular}{lccccccc}
\hline \multicolumn{1}{c}{ Kelompok } & $\mathrm{n}$ & $\mathrm{dk}$ & $\bar{X}$ & $\mathrm{~S}^{2}$ & $\mathrm{t}_{\text {hitung }}$ & $\mathrm{t}_{\text {tabel }}$ & Keterangan \\
\hline Eksperimen & 34 & \multirow{2}{*}{62} & 80,85 & 43,99 & 7,329 & 22,000 & $\mathrm{H}_{0}$ ditolak \\
Kontrol & 30 & & 66,85 & 75,99 & & & \\
\hline
\end{tabular}

Melalui uji hipotesis didapatkan harga thitung $=7,329$ dan harga $t_{\text {tabel }}=2,000$ untuk $\alpha=$ 0,05 dan $\mathrm{dk}=62$ maka $\mathrm{H}_{0}$ ditolak dan $\mathrm{H}_{\mathrm{a}}$ diterima. Jadi terdapat perbedaan yang signifikan kompetensi pengetahuan IPA antara kelompok siswa yang dibelajarkan dengan pendekatan contextual teaching and learning berbantuan media audio visual dengan kelompok siswa yang dibelajarkan menggunakan pembelajaran konvensional pada siswa kelas V SDN Gugus I Kuta Utara Tahun Ajaran 2019/2020. 
Hasil penelitian ini menunjukkan hal yang sama dengan hasil penelitian-penelitian sebelumnya yang serupa. Karena pembelajaran yang dirancang secara kontekstual dan dibantu dengan sumber belajar yang tepat akan memengaruhi kompetensi pengetahuan siswa. Temuan yang didapatkan pada pelaksanaan penelitian ini adalah siswa mampu mengkonstruksi sendiri pengetahuannya berkaitan dengan materi yang dipelajari, siswa lebih terotivasi dalam belajar karena digunakan media yang mearik perhatian siswa dan pembelajaran yang dirancang menjadi bermakna karena materi pembelajaran berkaaitan dengan hubungan kehidupan siswa sehari-harinya. Pada pembelajaran kontekstual guru berfungsi sebagai fasilitator, yakni membantu siswa mendapatkan makna (pengetahuan) (Ratih, 2014). Rusman (2016) menyatakan contextual teaching and learning, mendukung pendidik untuk memberi kaitan bahan ajar dengan keadaan nyata siswa saat proses belajar. Penggunaan pendekatan CTL, siswa dibantu mencapai tujuan dan didorong untuk membangun hubungan antara pengetahuannya dengan pelaksanaannya dalam keseharian sebagai bagian masyarakat (Dewi, 2017). Hal ini senada dengan pernyataan Winarti (2015) melalui kaitan di dalam dan di luar ruang belajar, pegetahuan siswa menjadi relevan karena pembelajaran dirancang kontekstual. Serta sejalan dengan pendapat Trisnadewi (2014) pendekatan CTL memberikan kesan yang menyenangkan bagi siswa karena siswa benarbenar ikut terlibat dalam kegiatan belajar, seperti halnya siswa menyampaikan pengetahuan yang dimiliki maka guru akan mengaitkan pemahaman yang didapat siswa dengan materi pelajaran saat itu. Hasil penelitian memperlihatkan pemilihan pendekatan CTL berbantuan media audio visual mampu mengefektifkan pengembangan proses belajar IPA. IPA sebagai muatan materi yang mempelajari ilmu tentang gejala alam, dengan bantuan pendekatan ini dapat memudahkan guru untuk mengaitkan muatan materi IPA dengan konteks kehidupan nyata. Berbantuan media audio visual, maka pembelajaran lebih menarik karena dibantu dengan unsur suara dan gambar. Berbeda halnya pada kelompok kontrol, kegiatan pembelajaran masih berpola konvensional sehingga pembelajaran kurang menarik dan siswa tidak cukup aktif pada kegiatan pembelajaran. Mengakibatkan tidak optimalnya kompetensi pengetahuan IPA siswa.

Terdapat tujuh tahapan pendekatan contextual teaching and learning yaitu kontruktivisme, inkuiri, menanya, masyarakat belajar, pemodelan, refleksi, penilaian sebenarnya (Trianto, 2015). Tahapan kontruktivisme bertujuan untuk menyiapkan struktur kognitif siswa dengan cara siswa membangun sendiri pengetahuannya, konstruktivisme juga memfokuskan pada belajar bukan hanya sekedar menghafal, melainkan pula merupakan proses pembelajaran yang mampu mengaktifkan siswa secara mental ketika membentuk pengetahuanya, yang didasari oleh pengetahuan yang dimilikinya. Jika bukan ditunjang dengan pengalaman yang nyata, pengetahuan teoritis yang bersifat hapalan mudah lepas dari ingatan seseorang. Tahap menemukan, hal yang diingat siswa lebih bersifat tahan lama jika dibandingkan dengan hanya diberikan guru semata, karena melalui kegiatan menemukan pengetahuan siswa bukan sekedar dari kegiatan mengingat saja namun pengetahuan dan kemampuan siswa merupakan hasil dari menemukan sendiri. Tahap ini juga siswa diminta membentuk perkiraan-perkiraan perihal fenomena yang hendak dipelajari kemudian di diskusikan pada tahap bertanya dan masyarakat belajar. Dalam tahap bertanya, peluang untuk bertanya diberikan kepada siswa mengenai masalah yang mereka temukan pada tahap sebelumnya, Melalui bertanya pengetahuan siswa bermula dan akan menjadikan pembelajaran lebih hidup, luas dan mendalam sehingga ditemukan unsur-unsur yang saling terkait. Pada tahap masyarakat belajar, siswa saling bekerja sama dan bertukar informasi. Kemudian pada tahap pemodelan siswa melakukan dan menuliskan hasil observasi dan ide atau gagasan melalui kegiatan seperti praktikum, Pemodelan dalam pendekatan ini membahasakan yang difikirkan, mendemontrasikan, sehingga keterbatasan yang dimiliki guru pada sumber belajar akan teratasi melalui kegiatan pemodelan yang membantu siswa dalam memahami pelajaran dan tahap pemodelan sebagai alternatif untuk mengembangkan pembelajaran.Tahap refleksi, guru meminta siswa mengingat ulang materi yang sudah diperoleh saat itu. Penelitian ini diperkuat bersama penelitian-penelitian yang telah ada 
sebelumnya seperti penelitian oleh Sugiarta (2013) menyimpulkan keaktifan dan prestasi belajar IPA siswa meningkat dengan diterapkannya pendekatan kontekstual (contextual teaching and learning). Hasil yang sama juga diperoleh Sari (2017) model pembelajaran inkuiri terbimbing berbantuan media audio visual memengaruhi kompetensi pengetahuan IPA siswa. Serta penelitian Yuasa (2014) hasil belajar IPA SD meningkat menggunakan pendekatan contextual teaching and learning berbantuan media animasi komputer.

Pemilihan pembelajaran yang sesuai dapat mempengaruhi pencapaian kompetensi pengetahuan peserta didik. Pembuktian bahwa pendekatan contextual teaching and learning berbantuan media audio visual tepat digunakan pada proses pembelajaran guna meningkatkan kompetensi pengetahuan IPA siswa, sehingga nantinya dapat tergeneralisasikan. Hasil penelitian ini juga dapat digunakan sebagai bahan masukan bagi guru dan calon guru. Hal yang dapat dilakukan adalah dengan membenahi dan meningkatkan kemampuan diri berkaitan dengan pembelajaran yang telah dilaksanakan dan kompetensi pengetahuan siswa yang telah dicapai dengan mencermati pembelajaran yang sesuai agar kompetensi pengetahuan IPA siswa meningkat.

\section{Simpulan}

Berdasarkan hasil analisis data maka disimpulkan pendekatan contextual teaching and learning berbantuan media audio visual berpengaruh terhadap kompetensi pengetahuan IPA siswa kelas V. Berikut saran-saran yang dapat disampaikan. Kepada guru, guru dapat memperoleh inspirasi dari hasil penelitian ini sehingga hendaknya guru dapat menerapkan model yang sama dengan penelitian ini khususnya pelajaran IPA. Kepada kepala sekolah, guna memajukan kualitas pembelajaran di sekolah penelitian ini juga berguna sebagai referensi. Kepada peneliti lain, penelitian ini dapat menjadi bahan sumber acuan peneliti lain untuk meneliti penelitian yang serupa.

\section{Daftar Pustaka}

Ariestuti, P. D., Darsana, I. W., \& Kristiantari, R. (2014). Penerapan Pendekatan Contextual Teaching And Learning (CTL) Untuk Meningkatan Keaktifan Dan Hasil Belajar IPA Siswa Kelas VI SDN 3 Tonja Tahun Ajaran 2014/2015. Jurnal Mimbar PGSD Universitas Pendidikan Ganesha, 2(1), 1-10.

Arsyad, A. (2013). Media Pembelajaran. Jakarta:Raja Grafindo Persada.

Astuti, Y., Mustaji, \& Prasetyo, K. (2015). Peningkatan Aktivitas dan Hasil Belajar Siswa Melalui Pendekatan Contextual Teaching and Learning dalam Pembelajaran IPS Kelas IVA SD Bawuran Kecamatan Pleret Kabupaten Bantul. Jurnal Review Pendidikan Dasar: Jurnal Kajian Pendidikan Dan Hasil Penelitian, 1(1), 20.

Dewi, D. A. P. H., Darsana, I. W., \& Manuaba, I. . S. (2018). Pengaruh Pendekatan Contextual Teaching and Learning Berbasis Penilaian Portofolio Terhadap Kompetensi Pengetahuan IPA. Journal for Lesson and Learning Studies, 1(3). https://doi.org/10.23887/jlls.v1i3.15387

Dewi, N. L. T., Putra, I. M., \& Suniasih, N. W. (2017). Pengaruh Pendekatan Contextual Teaching and Learning Berbasis Karakter Terhadap Hasil Belajar IPS Kelas IV SD Negeri Gugus Tuanku Imam Bonjol Kecamatan Denpasar Barat. MIMBAR PGSD Undiksha, 5(2).

Djamarah, S. B. dan A. Z. (2013). Strategi Belajar Mengajar. Jakarta:PT. Rineka Cipta.

Herlina, H. (2020). Upaya Meningkatkan Aktivitas dan Hasil Belajar Kimia dengan Pendekatan 
Contextual Teaching Learning di Kelas X SMAN 7 Rejang Lebong. PENDIPA Journal of Science Education, 4(1), 24-30. https://doi.org/10.33369/pendipa.4.1.24-30

Kasuma, I. P. A., Kristiantari, M. G. R., \& Ganing, N. N. (2017). Pengaruh Pendekatan Contextual Teaching and Learning (CTL) Terhadap Hasil Belajar Bahasa Indonesia. EJournal PGSD Universitas Pendidikan Ganesha Mimbar PGSD, 5(2), 1-10.

Mahardita, G. A. M. C., Abadi, I. B. G. S., \& Putra, M. (2017). Pengaruh Pendekatan Pembelajaran Kontekstual Berbantuan Media Visual Terhadap Hasil Belajar IPA Siswa Kelas V. E-Journal PGSD Universitas Pendidikan Ganesha Mimbar PGSD, 5(2), 1-9.

Marliani, S., Rengganis, I., \& Djumhana, N. (2018). Penerapan Pendekatan Contextual Teaching and Learning Untuk Meningkatkan Hasil Belajar IPA. Jurnal Pendidikan Guru Sekolah Dasar, 3(1), 35-42.

Nababan, S. A. (2018). Meningkatkan Prestasi Belajar Siswa dalam Pembelajaran Bangun Ruang Sisi Datar Melalui Implementasi CTL (Contextual Teaching and Learning) berbantuan Alat Peraga. Maju, 5(2), 130-141.

Paramita.A, N. L. P. A., Japa, I. G. N., \& Sudatha, I. G. W. (2019). Pengaruh Model Contextual Teaching and Learning Berbantuan Masalah Realistis Terhadap Keterampilan Berpikir Kritis IPA. Thinking Skills and Creativity Journal, 1(2), 56. https://doi.org/10.23887/tscj.v1i2.20499

Puspasari, K., Ardana, I. K., \& Putra, M. (2019). Pengaruh Pendekatan CTL Berbantuan Satua Bali Terhadap Kompetensi Sikap Sosial. Jurnal IImiah Sekolah Dasar, 3(4), 430-439.

Putri, N. (2018). Pembelajaran Materi Suhu dan Energi Panas Menggunakan Model Pembelajaran CTL (Contextual Teaching and Learning) pada Siswa MI. Universitas Muhammadiyah Sidoarjo.

Rahmawati, K. (2019). Implementasi Pendekatan Contextual Teaching and Learning (CTL) Dalam Pembelajaran Tematik Kelas V Di MI Ma'arif Nu Karangpucung, Purwokerto Selatan, Banyumas. Institut Agama Islam Negeri.

Ratih, N. K. A. N., Putra., I. K. A., \& Manuaba, I. B. S. (2014). Pengaruh Pendekatan Contextual Teaching And Learning (CTL) Melalui Pemodelan Media Sederhana Terhadap Hasil Belajar Matematika Siswa Kelas V SD Gugus III Kecamatan Gianyar. Journal Mimbar PGSD Universitas Pendidikan Ganesha, 2(1).

Riyanti, N. A. (2018). Pengaruh Model Pembelajaran Contextual Teaching and Learning (CTL) Terhadap Hasil Belajar Siswa di Madrasah ibtidaiyah Negeri 7 Tulungagung.

Rukajat, A. (2019). Pembelajaran Contextual Teaching and Learning Untuk Meningkatkan Mutu Hasil Pembelajaran. Pionir: Jurnal Pendidikan, 8(1).

Rusman. (2016). Model-Model Pembelajaran. Jakarta:PT Raja Grafindo Persada.

Samriani. (2016). Penerapan Pendekatan Contextual Teaching And Learning (CTL) Dalam Meningkatkan Hasil Belajar Siswa Pada Mata Pelajaran IPA di Kelas IV SDN No 3 Siwalempu. Jurnal Kreatif Tadulako Online, 4(2), 56-74. https://doi.org/10.1111/j.15264610.2004.446003.x

Sari, N. L. B. A., Putra, I. K. A., \& Wiarta, I. W. (2017). Pengaruh Model Pembelajaran Inkuiri 
Terbimbing Berbantuan Media Audio-Visual Terhadap Kompetensi Pengetahuan IPA Siswa Kelas IV. E-Journal Pendidikan Universitas Pendidikan Ganesha Program Studi $P G S D, 5(2), 1-11$.

Sulfemi, W. B. (2019). Model Pembelajaran Contextual Teaching And Learning (CTL) Berbantu Media Miniatur Lingkungan Untuk Meningkatkan Hasil Belajar IPS. Edunomic: Jurnal IImiah Pendidikan Ekonomi Fakultas Keguruan Dan Ilmu Pendidikan, 7(2), 73-84.

Sugiarta, I. G., Dantes, N., \& I Wayan, S. (2013). Penerapan Pendekatan Kontekstual (Contextual Teaching and Learning) Untuk Meningkatkan Keaktifan Siswa Kelas IV Tahun Pelajaran 2012/2013 DI SD NO. 3 Pegayaman Kecamatan Sukasada. E-Journal Program Pascasarjana Universitas Pendidikan Ganesha Jurusan Pendidikan Dasar, 3(2).

Suprianto, S., Kholida, S. I., \& Andi, H. J. (2016). Pengaruh Pendekatan Contextual Teaching and Learning (CTL) Berbantuan Media Powerpoint Terhadap Peningkatan Hasil Belajar IPA Fisika. Jurnal Penelitian Dan Pembelajaran IPA, 2(2), 166-175. https://doi.org/10.30870/jppi.v2i2.427

Trianto. (2015). Mendesain Model Pembelajaran Inovatif, Progresif, dan Kontekstual:Konsep, Landasan, dan Implementasi pada Kurikulum 2013 (Kurikulum Tematik Integratif/TKI). Jakarta: Prenadamedia Group.

Trisnadewi, K. A., Darsana, I. W., \& Wiyasa, I. K. N. (2014). Penerapan Pembelajaran Inkuiri Berbantuan Media Audiovisual Untuk Meningkatkan Aktivitas dan Hasil Belajar IPS Siswa Kelas V SD NO. 3 Tibubeneng, Kuta Utara. E-Jurnal Mimbar PGSD Universitas Pendidikan Ganesha Jurusan PGSD, 2(1).

Widiasworo. (2018). Strategi Pembelajaran Edutaiment Berbasis Karakter. Yogyakarta:ARRuzz Media.

Winarti. (2015). Contextual Teaching and Learning (CTL) Untuk Meningkatkan Kemampuan Berpikir Kreatif Siswa. Jurnal Pendidikan Fisika Dan Keilmuan (JPFK), 1(1), 1-8. https://doi.org/10.25273/jpfk.v1i1.4

Wiyono, B. H., \& Budhi, W. (2018). Pengaruh metode pembelajaran CTL terhadap hasil belajar IPA siswa kelas VIII ditinjau dari kemampuan berkomunikasi. Natural: Jurnal IImiah Pendidikan IPA, 5(1), 11-18.

Yuasa, I. P., Ardana, I. K., \& Suadnyana, I. N. (2014). Pengaruh Pendekatan Contextual Teaching and Learning Berbantuan Media Animasi Komputer Terhadap Hasil Belajar Sd Gugus 1 Tampaksiring. Jurnal Mimbar PGSD Universitas Pendidikan Ganesha Jurusan PGSD, 2(1). 